\title{
NURSE JOB SATISFACTION AT A SURGICAL WARD - A COMPARATIVE STUDY BETWEEN SWEDEN AND POLAND
}

\author{
Lena Serafin ${ }^{1}$, Kristofer Bjerså2 ${ }^{2}$, Anna Doboszyńska ${ }^{3}$ \\ ${ }^{1}$ Medical University of Warsaw, Warsaw, Poland \\ Faculty of Health Science, Clinical Nursing Department \\ ${ }^{2}$ Linköping University, Linköping, Sweden \\ Faculty of Medicine and Health Sciences \\ ${ }^{3}$ University of Warmia and Mazury in Olsztyn, Olsztyn, Poland \\ Pulmonology Department, Nursing Department
}

\begin{abstract}
Background: Job satisfaction is a major issue in work psychology among nurses, and in the surgical nursing context, important factors leading to the perception of job satisfaction have been suggested. Two European Union neighboring countries (Sweden and Poland) were chosen for the purpose of this study due to similar nursing education but different health care systems, employment regulations and salaries. Recognition of the factors which are related to nurse job satisfaction may lead to improvements in the nurses' working conditions. The aim of this study was to explore and compare job satisfaction and various factors among Polish and Swedish nurses in a surgical ward context. Material and Methods: The study had a cross-sectional survey design, with questionnaires among Polish and Swedish nurses in surgical care, and was conducted between April and December 2014. The main assessment tool was a Job Satisfaction Survey questionnaire. In total, 408 nurses returned the questionnaire (response rate - 59\%). Results: Swedish nurses rated job satisfaction significantly higher than Polish nurses. The possibilities for professional development at the current workplace correlated with job satisfaction in both groups. Higher values of exhaustion due to nurses' working duties were correlated with general job satisfaction. Conclusions: Swedish and Polish nurses showed ambivalence towards job satisfaction. Their job satisfaction increased when their exhaustion level was higher. The possibilities for achievements, developing professional skills, and promotion may be important factors affecting job satisfaction. Med Pr. 2019;70(2):155-67
\end{abstract}

Key words: job satisfaction, nurses, European Union, surgical care, management in nursing, working conditions

Corresponding author: Lena Serafin, Medical University of Warsaw, Clinical Nursing Department, Erazma Ciołka 27, 01-445 Warsaw, Poland, e-mail: lkozlowska@wum.edu.pl

Received: April 5, 2018, accepted: July 25, 2018

\section{INTRODUCTION}

Job satisfaction is a common research area in work-related psychology. The basics of this issue originate from Maslow's hierarchy of needs [1]. The first to identify the determinants of job satisfaction was Herzberg, with the 2 -factor theory. These factors were: motivators (e.g., recognition for achievement, responsibility, meaningfulness and advancement), and hygiene factors (e.g., working conditions, salary, security and status) [2].

Furthermore, Spector defined job satisfaction as "the extent to which people like or dislike their jobs," meaning people's general attitude towards their job and its various aspects [3]. Both external factors (e.g., technical condition, car parking, personal fulfillment) and internal ones (e.g., age, gender, personal ability) have an influence on job satisfaction [1]. Furthermore, the possibility for personal development and self-realization is also an important factor [1]. One of the concepts of work-related psychology states that employees' engagement is an essential work aspect [4]. The study among nurses has shown that health care management should consider nurses' engagement and well-being in everyday decision-making because these factors are related to the level of commitment that nurses have, which is a strong predictor of retention [5]. Additionally, employees' engagement is an important predictor of job satisfaction and intentions to remain in a workplace [6].

Job satisfaction in the nursing profession is also important as it has been proven to influence nurses' retention in a workplace [7]. Nursing staff with a high level of job satisfaction is important for high quality care, as evaluated by patients [8], while work dissatisfaction is related to reduced safety and satisfaction of patients [9]. Evidence has shown that higher burnout levels among nurses caused by work stress are associated with lower job satisfaction [10]. Burnout is a predictor of job satisfaction [11]. Moreover, highly satisfied and free from burnout nurses 
would be effective in providing quality nursing care since their ultimate goal is the patient's satisfaction [12].

Important factors affecting job satisfaction among nurses are possibilities for professional development [13], supervision and management [14], the rewards offered by the job [12], working conditions, promotion and selfgrowth [15]. Studies conducted among surgical nurses revealed that the level of job satisfaction was influenced by achievements, remuneration, autonomy and supportive work environment $[16,17]$. Following the factors affecting job satisfaction, the authors decided to utilize the Job Satisfaction Survey questionnaire [18] as a research tool, which had been used before, also as a reliable tool in studies among nurses - Cronbach's $\alpha>0.7$ [19-21].

Approximately $77 \%$ of Swedish nurses are moderately or very satisfied with their current job [22]. Swedish nurses indicate that social support is the best predictor of job satisfaction, followed by role conflicts, role clarity, qualitative demands, the impact of the manager's role, and opportunities for self-development [14]. According to previous Polish studies, nurses' job satisfaction is influenced by interpersonal relationships in the workplace, the existence of a good atmosphere, a lack of opportunity for self-development, contingent rewards and low remuneration $[23,24]$.

Job satisfaction is frequently studied with an assistance of Herzberg's 2-factor theory. As previous studies revealed in both countries, such motivators as job atmosphere, social support, relations with colleagues and the manager, and opportunities for self-development had a major influence on nurses' job satisfaction [14,23]. Additionally, in Poland nurses have pointed out the importance of hygiene factors such as remuneration [24].

Job satisfaction assessment using the same scale among nurses in the 2 European Union countries could be helpful in developing comparable job markets. Recognition of the factors which have an influence on job satisfaction may lead to improvements in nurses' working conditions. Moreover, Sweden and Poland are neighboring countries but with significantly different national economies and social systems. Polish and Swedish nurses are currently educated within a similar academic structure, based on Directive 2013/55/EU of the European Parliament and of the Council [25]. Nursing programs in both countries are provided at a university level and include a Bachelor of Science degree in nursing. Despite the similarities in nursing education and the fact that both Sweden and Poland are members of the European Union, the 2 countries' health care systems, employment regulations and salaries differ. Both Swed- ish and Polish health care systems are mainly provided by the public sector. The idea is that everyone has equal access to health care services, but the sources of funding are different. In Poland, as well as Sweden, nurses can continue their education on postgraduate courses. For example, they can obtain the surgical nurse specialist title. The management career pathway is another career pathway, separate from the clinical one. A marked difference is the number of nurses per 1000 inhabitants: in Poland - 5.4 [26] and in Sweden - 11.1 [27]. The difference in the use of nurse assistants is also important in Sweden, as well as in other European countries, but it has not been implemented into the Polish health care system in general. It is currently unknown if these country-specific differences influence nurses' perceptions of job satisfaction.

To investigate this, one of the least investigated areas of nursing practice as regards the subject of job satisfaction has been chosen, namely surgical care. There is previous research among surgical nurses which has revealed a moderate level of general job satisfaction $[16,17]$. The studies have shown that surgical nurses indicate different factors of job satisfaction than other nurses [28] and they present higher motivation [29]. Therefore, the study was conducted among uniform groups of respondents in order to provide reliable results. In order to make a comparative regional health care level, hospitals in the capitals of Sweden (Stockholm) and Poland (Warsaw) were included in the scope of this study, too.

Hence, the aim of this study was to explore and compare job satisfaction and factors affecting it among Polish and Swedish nurses at surgical wards.

\section{MATERIAL AND METHODS}

A cross-sectional survey design utilizing questionnaires was selected to fulfill the research objectives.

\section{Sample and setting}

The study was carried out among registered nurses at surgical wards in hospitals in the capitals of Poland and Sweden. Inclusion criteria were as follows: holding at least a Bachelor's degree in nursing science, and working in the current unit for at least 3 months. Exclusion criteria included working in a non-clinical position, such as management, research or development.

\section{Data collection}

Data collection for this study was performed in Poland and Sweden between April and December 2014 (Figure 1). 


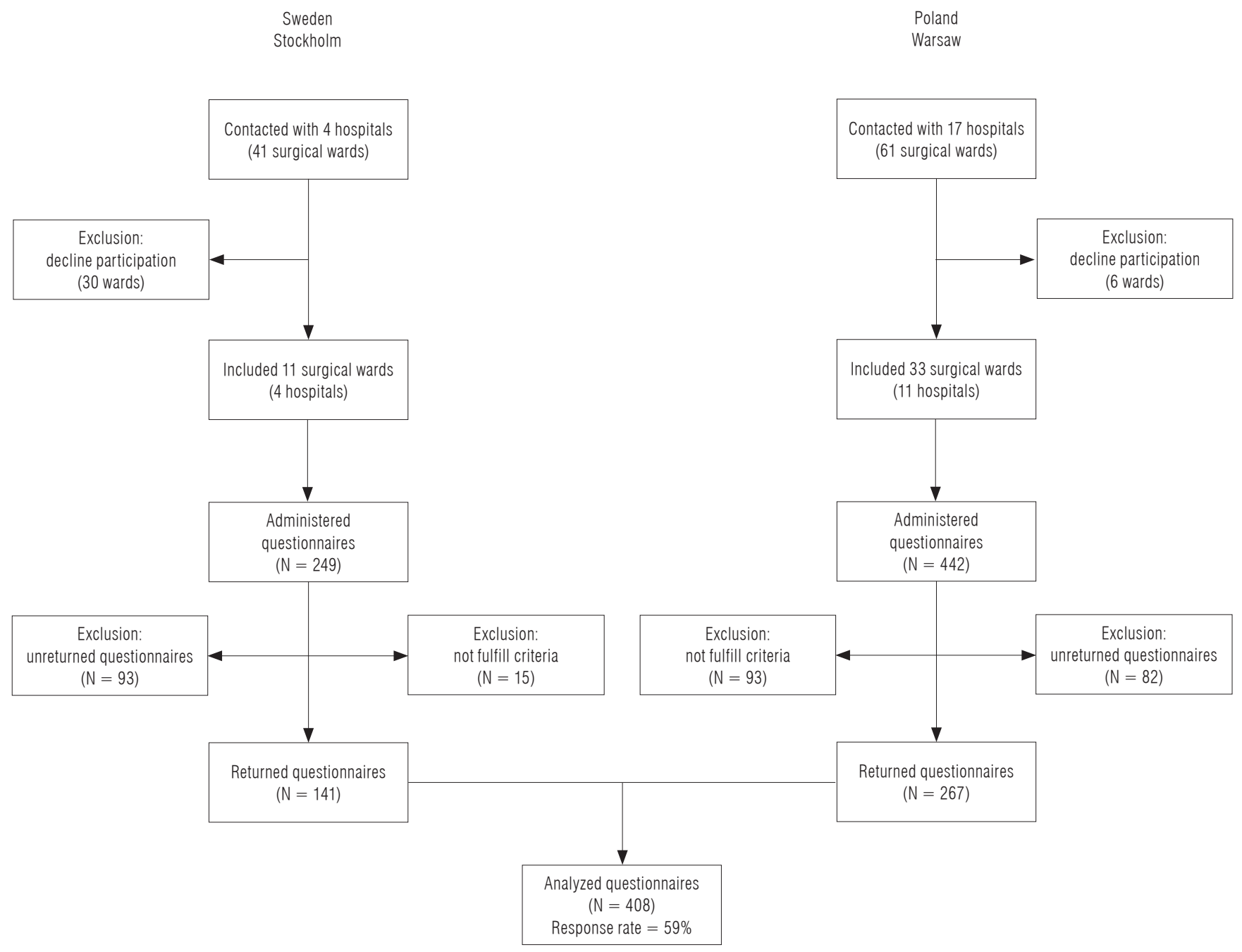

Figure 1. Participant recruitment and questionnaire distribution among Swedish and Polish nurses

In Poland, nurses employed at 18 Warsaw-based hospitals connected to the National Health Service participated in the study. Hospital directors in these hospitals were contacted by phone or personally, the study was explained, and a request for permission to gather data was sought. Out of the 18 hospital directors contacted, 12 gave their permission to perform the data collection process. One of these hospitals was used for a pilot study, resulting in the inclusion of 11 Polish hospitals in the results. These included 33 surgical wards within the areas of general surgery, gastroenterology, hepatology, neurosurgery, otolaryngology, thoracic, cardiac, transplantation, vascular, endocrine, orthopedics, and oncology surgery. In total, 442 questionnaires were administered to Polish nurses and 267 were returned (response rate of $60.4 \%$ ).
In Sweden, nurses employed at 41 wards in the 4 largest hospitals in the Stockholm region participated in the study. Nurse managers at the wards were contacted by phone or e-mail, the study was explained, and a request for permission to gather data was sought. Out of the 41 contacted wards, 11 responded and gave their permission to perform the data collection process. These included wards within the areas of orthopedics, neurology, urology, gastroenterology, otolaryngology, thoracic, and gynecology. In total, 249 questionnaires were administered to Swedish nurses and 141 were returned (response rate of 56.6\%).

Distribution in both Poland and Sweden was through the nurses' personal mail boxes at the wards. The questionnaires were distributed with a blank envelope. Each ward received a study-specified mail box for returning the filled-out questionnaires. To protect the respondents' 
anonymity, the filled-out questionnaires were returned via locked mail boxes in each ward, having been sealed into paper envelopes. The mailbox was emptied once a week during data collection.

\section{Instrument}

Data collection was performed with a joint questionnaire consisting of 4 parts:

1. The first part was the fact sheet describing the study background, study aim, request for participation and research ethics.

2. The second part contained the Polish or Swedish translations of the questionnaire instrument, i.e., Spector's Job Satisfaction Survey (JSS) [18], henceforth referred to as Job Satisfaction I. The JSS measures job satisfaction and has 9 facets, based on 4 items each, with a total of 36 items scored on a 6-point Likert scale. The items were rated on a scale ranging from 1 (strongly disagree) to 6 (strongly agree). Nineteen of them, which are negatively worded, have been reversed before summing with the positively worded ones. It investigates attitudes to pay, promotion, supervision, fringe benefits, contingent rewards, operating conditions, coworkers, nature of work, and communication. The JSS has been developed for the use in human service organizations, and it is also used among nurses [19-21]. Previous studies were conducted among nurses within surgical, neurosurgical, cardiac, pediatric and psychiatric care. The instrument is perceived as reliable and valid, with Cronbach's $\alpha$ of 0.91 for the overall scale [18].

3. The third part consisted of 12 main questions (28 items), and was constructed based on a literature review of nurses' job satisfaction [23,30]. It was mainly scored on a 6-point Likert scale; items were rated on a scale ranging from 1 (strongly disagree) to 6 (strongly agree). Answers to the question referring to the time which nurses spent on each duty were expressed in percentage terms. The aim of this section was to measure specific working conditions of a registered nurse (Appendix 1). It will henceforth be referred to as Job Satisfaction II.

4. The fourth part consisted of demographic questions on matters such as age, gender, marital status, education, seniority, employment status and employment form, salary and working system.

In the Polish part of the study, the JSS version translated by Chirkowska-Smolak was used [18].

No Swedish translation of the instrument was found. The English version of the JSS was instead validly translated by 2 independent translations and then back-translated.
Translation was done firstly by 2 independent professional translators who translated the original English version of the JSS into Swedish, and then, after the synthesis of this translation, which was performed inside the research group, another two independent translators translated it back into English.

The questionnaire was piloted and investigated for face validity in both Poland and Sweden. The Polish version of the questionnaire was evaluated for test-retest reliability (conducted among 10 nurses in a 2-week period). The result showed the stability of the test over time $(r=0.77)$. The internal consistency of the tool was measured by Cronbach's $\alpha$. The total value for Job satisfaction I was 0.82 and for Job satisfaction II - 0.79.

The Swedish version of the Job satisfaction II questionnaire was prepared based on the Polish version using 2 independent translations and back-translation.

A pilot study group consisting of 8 Swedish registered nurses from surgical wards in Gothenburg, Sweden, filled out the questionnaire and answered specific questions concerning face validity. Only minor adjustments were then made to the questionnaire. After the pilot study had been conducted in both groups, the authors decided to change the demographic part of the study in the Swedish and Polish versions (excluding 2 questions concerning the number of beds in the wards and the number of beds in a hospital). Additional minor language adjustments to the Swedish questionnaires were made due to different health care nomenclature.

\section{Analysis}

All the data was analyzed using IBM SPSS Statistics, version 22. For descriptive data, exact and relative values, percentage rates, mean and standard deviation, as well as median and range (min.--max) were calculated.

To evaluate the JSS results, average values were calculated for each 4-item subscale, as well as for the entire tool consisting of 36 questions (after reverse scoring of the negatively-worded items).

Cross tabulation was calculated for the distribution of nominal data, where the Pearson $\mathrm{Chi}^{2}$ test was used for significance testing of the relationship between countries regarding various factors (the number of hours nurses spend in their work per week, work system). Furthermore, the Pearson $\chi^{2}$ test was utilized to compare gender, education, form of employment, hours of work per week, hours per shift and time nurses spent on some duties.

For comparison between the 2 groups regarding ordinal categorical data, such as time and working duties, 
the Mann-Whitney U test was used. For comparison between the 2 groups regarding interval data, such as the level of presented job satisfaction, years in nursing, working at a current place and salary, an unpaired Student's t-test was used.

To assess correlations between job satisfaction and its facets, and 11 questions of Job Satisfaction II and demographic variables, the Pearson product-moment correlation coefficient $\left(r_{p}\right)$ was used. Moreover, Spearman's rank correlation coefficient $\left(r_{s}\right)$ was used for assessing the correlation between job satisfaction and its facets, and the time nurses spent on some duties. Only correlation coefficients $>0.3$ were presented. Correlation levels were set low in the interval $r=0.30-0.39$, moderate $r=0.40-0.59$, and high $r>0.6$. An acceptable level for statistical significance was set at $p(\alpha) \leq 0.05$.

\section{Ethical considerations}

The ethical issues were reviewed and approved by the Ethical Board at the Medical University of Warsaw (AKBE/ 68/13) which was in accordance with the Swedish law on ethics in research (Prop. 2007/08:44, Law 2003:460) [31]. All participants were informed on the aim of the study in writing, namely about the principles of voluntary participation and anonymity, and that their work and employment would not be affected whether or not they chose to participate. Returning the questionnaire was deemed to signify full acceptance of participation in the study. Ethical considerations in this study followed the Helsinki Declaration regarding research on human subjects.

A permission for study participation and questionnaires distribution was obtained from hospital directors in Poland and ward nurse managers or matrons in Sweden.

\section{RESULTS}

In total, 408 questionnaires were returned (the response rate was 59\%). Participant demographics are presented in Tables 1 and 2.

A statistically significant difference $(\mathrm{p}<0.001)$ between the Polish and Swedish participants $(\mathrm{N}=400)$ was observed in the years in nursing and the years of employment at the current workplace. Swedish nurses had significantly less work experience ( $\mathrm{p}<0.001$, $\mathrm{N}=400$ ), as well as fewer years of employment at their current workplace, as compared to Polish nurses (Table 1).

The majority of Polish nurses worked in a 12-h system (84.6\%, N = 226), and Swedish nurses worked mainly in an 8 -h system $(92.1 \%, \mathrm{~N}=129)$. In both countries, nurses usually worked $36-45 \mathrm{~h}$ per week (Poland $-67.4 \%$, $\mathrm{N}=180$; Sweden $-78.7 \%, \mathrm{~N}=111$ ). Moreover, $5.8 \%$ $(\mathrm{N}=15)$ of Polish nurses worked over $56 \mathrm{~h}$ per week, which did not occur at all among Swedish nurses. There were significant differences between Polish and Swedish nurses in the amount of time they spent on talking with patients' families and relatives $(\mathrm{p}<0.001)$, administration (maintaining complete medical records, reports of patients' medical histories, adequate supplies) $(p<0.001)$ and other duties $(p<0.001)$. Swedish respondents spent more time talking with patients' families and relatives (Poland $-10.8 \%$ of the working time, $\mathrm{N}=234$; Sweden $-12.9 \%, \mathrm{~N}=139$ ), and Polish nurses spent more time on administration and other duties (Poland $-33.2 \%$ of the working time, $\mathrm{N}=234$; Sweden - 20.8\%, $\mathrm{N}=139$ ).

Statistically significant differences in salary $(\mathrm{p}<0.001$, $\mathrm{N}=349$ ) were observed between the 2 countries (Poland - EUR 533/month, Sweden - EUR 2717/month).

\section{Job satisfaction}

In general, job satisfaction as measured by Job Satisfaction I was rated in both groups at a moderate level (Table 3). However, a statistically significant difference ( $\mathrm{p}=0.003, \mathrm{~N}=408$ ) was observed in Job Satisfaction I between the countries whereas Swedish nurses valued their job satisfaction significantly higher than their Polish colleagues. No statistically significant difference was observed for Job Satisfaction II ( $\mathrm{p}=0.177$, $\mathrm{N}=408$ ). Statistically significant differences between the countries were found in all facets of Job Satisfaction I except for communication (Table 3); only satisfaction with communication in their job was similar in both groups ( $p=0.198, N=408$ ). The levels of job satisfaction among both Swedish and Polish nurses were rated as "ambivalent attitudes regarding job satisfaction" (scores 3-4) according to the Job Satisfaction I levels of job satisfaction [3].

According to the results of Job Satisfaction II, just over a half of Polish $(56.5 \%, \mathrm{~N}=151)$ and Swedish $(59.6 \%, \mathrm{~N}=84)$ nurses claimed that their potential was exploited properly. However, Swedish nurses were more satisfied with occupational development at their current employment $(39.7 \%, \mathrm{~N}=56)$. Among Polish nurses, only $25.5 \%(\mathrm{~N}=68)$ of the respondents confirmed this statement. Twice as many Polish nurses $(30.7 \%$, $\mathrm{N}=82)$ - as compared to Swedish nurses $(14.2 \%, \mathrm{~N}=20)$ declared that they did not have working conditions good enough to perform high quality care. As far as ex- 
Table 1. A comparison of demographics of the participants - Polish $(\mathrm{N}=267)$ and Swedish nurses $(\mathrm{N}=141)$

\begin{tabular}{|c|c|c|c|c|c|c|c|c|}
\hline \multirow{3}{*}{ Variable } & \multicolumn{8}{|c|}{ Nurses } \\
\hline & \multicolumn{2}{|c|}{ Swedish } & \multicolumn{2}{|c|}{ Polish } & \multicolumn{2}{|c|}{ total } & \multicolumn{2}{|c|}{$\begin{array}{l}\text { comparison of demographic } \\
\text { of Polish and Swedish nurse }\end{array}$} \\
\hline & $\%$ & $\mathrm{n}$ & $\%$ & $\mathrm{n}$ & $\%$ & $\mathrm{n}$ & $\mathrm{p}$ & $\mathrm{n}$ \\
\hline Gender & & & & & & & 0.023 & 408 \\
\hline women & 90.8 & 128 & 96.2 & 257 & 94.3 & 385 & & \\
\hline men & 9.2 & 13 & 3.8 & 10 & 5.7 & 23 & & \\
\hline Highest educational level & & & & & & & $<0.001$ & 402 \\
\hline Bachelor of Science in nursing & 88.6 & 125 & 67.8 & 177 & 75.1 & 302 & & \\
\hline specialist nurse diploma & 7.8 & 11 & 3.1 & 8 & 4.7 & 19 & & \\
\hline Master of Science in nursing & 3.6 & 5 & 29.1 & 76 & 20.2 & 81 & & \\
\hline Current form of employment & & & & & & & 0.346 & 408 \\
\hline permanent & 92.9 & 131 & 93.6 & 250 & 93.4 & 381 & & \\
\hline part-time & 6.4 & 9 & 0 & 0 & 2.2 & 9 & & \\
\hline by the hour & 0.7 & 1 & 3.7 & 10 & 2.7 & 11 & & \\
\hline other forms & 0 & 0 & 2.7 & 7 & 1.7 & 7 & & \\
\hline Working time [h/week] & & & & & & & $<0.001$ & 398 \\
\hline$\leq 20$ & 0.7 & 1 & 1.1 & 3 & 1.0 & 4 & & \\
\hline $21-35$ & 17.0 & 24 & 10.0 & 26 & 12.6 & 50 & & \\
\hline $36-45$ & 78.7 & 111 & 67.4 & 180 & 73.1 & 291 & & \\
\hline $46-55$ & 3.5 & 5 & 11.5 & 33 & 9.5 & 38 & & \\
\hline$\geq 56$ & 0 & 0 & 5.7 & 15 & 3.8 & 15 & & \\
\hline Working duty & & 139 & & 234 & & 373 & & 373 \\
\hline bedside care & 45.5 & & 43.8 & & 44.7 & & 0.461 & \\
\hline patient education & 12.3 & & 12.6 & & 12.5 & & 0.489 & \\
\hline $\begin{array}{l}\text { talking with the patients' } \\
\text { families and relatives }\end{array}$ & 12.9 & & 10.8 & & 11.6 & & 0.001 & \\
\hline $\begin{array}{l}\text { administration and } \\
\text { documentation }\end{array}$ & 20.8 & & 33.2 & & 28.4 & & $<0.001$ & \\
\hline others & 8.9 & & 14.7 & & 11.2 & & $<0.001$ & \\
\hline Work system & & & & & & & $<0.001$ & 407 \\
\hline 12-hour shift & 2.9 & 4 & 84.6 & 226 & 56.5 & 230 & & \\
\hline $\begin{array}{l}\text { 8-h shift (morning/ } \\
\text { afternoon/night) }\end{array}$ & 55.7 & 78 & 0.7 & 2 & 19.7 & 80 & & \\
\hline 8-h shift (morning) & 36.4 & 51 & 13.5 & 36 & 21.4 & 87 & & \\
\hline other systems & 5.0 & 7 & 1.1 & 3 & 2.5 & 10 & & \\
\hline
\end{tabular}

haustion was concerned, the majority of Polish $(79.1 \%$, $\mathrm{N}=204)$ and Swedish nurses $(66.2 \%, \mathrm{~N}=92)$ declared they were exhausted.

No correlation of job satisfaction measured by Job Satisfaction II among Polish nurses was found with age $\left(\mathrm{r}_{\mathrm{p}}=0.220, \mathrm{p}=0.001, \mathrm{~N}=256\right)$, years as a registered nurse $(\mathrm{RN})\left(\mathrm{r}_{\mathrm{p}}=0.254, \mathrm{p}<0.001, \mathrm{~N}=261\right)$, or years at the current workplace $\left(r_{p}=0.143, p=0.024, \mathrm{~N}=255\right)$. Among Swedish respondents, no correlation was found between Job Satisfaction II and age $\left(\mathrm{r}_{\mathrm{p}}=-0.020\right.$, $\mathrm{p}=0.819, \mathrm{~N}=138)$, years as a $\mathrm{RN}\left(\mathrm{r}_{\mathrm{p}}=-0.133, \mathrm{p}=0.129\right.$, $\mathrm{N}=139)$ and years at the current workplace $\left(\mathrm{r}_{\mathrm{p}}=-0.095\right.$, 
Table 2. A comparison of demographics of the participants - Polish $(\mathrm{N}=267)$ and Swedish nurses $(\mathrm{N}=141)$

\begin{tabular}{|c|c|c|c|c|c|c|c|c|}
\hline \multirow{2}{*}{ Variable } & \multicolumn{8}{|c|}{ Nurses } \\
\hline & $\mathrm{M} \pm \mathrm{SD}$ & $\mathrm{n}$ & $\mathrm{M} \pm \mathrm{SD}$ & $\mathrm{n}$ & $\mathrm{M} \pm \mathrm{SD}$ & $\mathrm{n}$ & $\mathrm{p}$ & $\mathrm{n}$ \\
\hline Age [years] & $34.3 \pm 9.6$ & 139 & $38.2 \pm 9.8$ & 256 & $36.8 \pm 9.7$ & 395 & $<0.001$ & 395 \\
\hline $\begin{array}{l}\text { Time of being a registered } \\
\text { nurse [years] }\end{array}$ & $8.5 \pm 8.3$ & 139 & $16.0 \pm 10.9$ & 261 & $13.3 \pm 10.6$ & 400 & $<0.001$ & 400 \\
\hline Current salary (net) [EUR] & $2717 \pm 415.2$ & 131 & $533 \pm 10.5$ & 218 & $1362 \pm 1094.7$ & 349 & $<0.001$ & 400 \\
\hline
\end{tabular}

Table 3. Job satisfaction in general and by dimensions

\begin{tabular}{|c|c|c|c|c|c|c|c|c|c|c|c|}
\hline \multirow{4}{*}{ Variable } & \multicolumn{11}{|c|}{ Nurses' job satisfaction* } \\
\hline & \multicolumn{2}{|c|}{$\begin{array}{l}\text { Swedish } \\
(\mathrm{N}=141)\end{array}$} & \multicolumn{2}{|c|}{$\begin{array}{c}\text { Polish } \\
(\mathrm{N}=267)\end{array}$} & \multicolumn{2}{|c|}{$\begin{array}{c}\text { total } \\
(\mathrm{N}=408)\end{array}$} & \multicolumn{5}{|c|}{$\begin{array}{l}\text { Swedish vs. Polish } \\
\qquad(\mathrm{N}=408)\end{array}$} \\
\hline & \multirow{2}{*}{$\mathrm{M}$} & \multirow{2}{*}{$\mathrm{SD}$} & \multirow{2}{*}{ M } & \multirow{2}{*}{ SD } & \multirow{2}{*}{ M } & \multirow{2}{*}{ SD } & \multirow{2}{*}{$\mathrm{t}$} & \multirow{2}{*}{$\mathrm{p}$} & \multicolumn{2}{|c|}{$95 \%$ CI } & \multirow{2}{*}{$\begin{array}{c}\text { Cohen's } \\
\text { d }\end{array}$} \\
\hline & & & & & & & & & LL & UL & \\
\hline Job satisfaction I & 3.61 & 0.4 & 3.1 & 0.54 & 3.28 & 0.6 & -9.931 & 0.003 & -0.599 & -0.401 & 0,979 \\
\hline pay & 2.5 & 0.9 & 1.9 & 0.9 & 2.1 & 1.0 & -6.465 & $<0.001$ & -0.817 & -0.436 & 0.673 \\
\hline promotion & 2.9 & 0.9 & 2.4 & 1.1 & 2.6 & 1.0 & -5.150 & $<0.001$ & -0.718 & -0.321 & 0.507 \\
\hline supervision & 4.7 & 1.1 & 4.2 & 1.1 & 4.4 & 1.1 & -4.051 & $<0.001$ & -0.710 & -0.246 & 0.423 \\
\hline fringe benefits & 2.8 & 1.0 & 2.5 & 1.0 & 2.6 & 1.0 & -3.196 & 0.002 & -0.523 & -0.125 & 0.333 \\
\hline contingent rewards & 3.1 & 0.8 & 2.1 & 0.9 & 2.5 & 1.1 & -13.120 & $<0.001$ & -1.418 & -1.048 & 1.366 \\
\hline operating conditions & 3.2 & 0.7 & 2.6 & 1.0 & 2.9 & 0.9 & -6.943 & $<0.001$ & -0.764 & -0.427 & 0.669 \\
\hline coworkers & 3.7 & 0.8 & 4.2 & 0.9 & 4.7 & 0.9 & -3.581 & $<0.001$ & -0.502 & -0.146 & 0.373 \\
\hline nature of work & 3.6 & 0.8 & 4.5 & 1.0 & 4.6 & 0.9 & -2.996 & 0.003 & -0.477 & -0.099 & 0.312 \\
\hline communication & 4.5 & 1.0 & 3.5 & 1.0 & 3.6 & 1.0 & -1.288 & 0.198 & -0.340 & 0.071 & 0.134 \\
\hline Job satisfaction II & 4.5 & 0.6 & 4.4 & 0.7 & 4.4 & 0.6 & -9.045 & 0.177 & -0.561 & -0.098 & 0.392 \\
\hline
\end{tabular}

* Assessed on a 1-6 scale, where 1 - "strongest disagreement" to 6 - "strongest agreement."

$\mathrm{t}$ - t-student test, CI - confidence interval, LL - lower limit, UL - upper limit.

Job Satisfaction I - the level of job satisfaction assessed with the Job Satisfaction Survey questionnaire, Job Satisfaction II - the level of job satisfaction assessed with the authors' tool.

$\mathrm{p}=0.279, \mathrm{~N}=139$ ). Thus, the time which Polish nurses spent on talking with patients' relatives had a weak positive correlation with the satisfaction with salary $\left(r_{s}=0.369, p<0.001, \mathrm{~N}=267\right)$, promotion $\left(r_{s}=0.326\right.$, $\mathrm{p}<0.001, \mathrm{~N}=267)$ and general job satisfaction, as measured by Job Satisfaction I $\left(\mathrm{r}_{\mathrm{s}}=0.342, \mathrm{p}<0.001\right.$, $\mathrm{N}=267$ ). No correlations were found between the time Swedish nurses spent on "other duties" and job satisfaction (Table 4). Neither the responses from Polish $\left(r_{p}=0.063, p=0.374, \mathrm{~N}=231\right)$ nor Swedish nurses $\left(r_{p}=0.214, p=0.017, N=131\right)$ showed any correlation between the pay facet and the amount of salary.

Higher values of exhaustion due to working duties among Polish nurses were positively correlated with general job satisfaction measured by Job Satisfaction I $\left(r_{p}=0.346, p<0.001, N=267\right)$. Among Swedish nurses, being exhausted was weakly positively correlated with the nature of work $\left(\mathrm{r}_{\mathrm{p}}=0.327, \mathrm{p}<0.001, \mathrm{~N}=141\right)$, and moderately with Job Satisfaction $I\left(\mathrm{r}_{\mathrm{p}}=0.425\right.$, $\mathrm{p}<0.001, \mathrm{~N}=141$ ).

When it came to being utilized sufficiently as a registered nurse, $56.7 \%(\mathrm{~N}=148)$ of Polish and 59.6\% $(\mathrm{N}=84)$ of Swedish nurses agreed with that statement. Among Polish nurses, the possibilities for development at the current workplace were weakly and positively correlated with promotion $\left(\mathrm{r}_{\mathrm{p}}=0.357, \mathrm{p}<0.001, \mathrm{~N}=267\right)$ and Job Satisfaction $I\left(\mathrm{r}_{\mathrm{p}}=0.313, \mathrm{p}<0.001, \mathrm{~N}=267\right)$. Furthermore, good ratings of being utilized as a nurse 


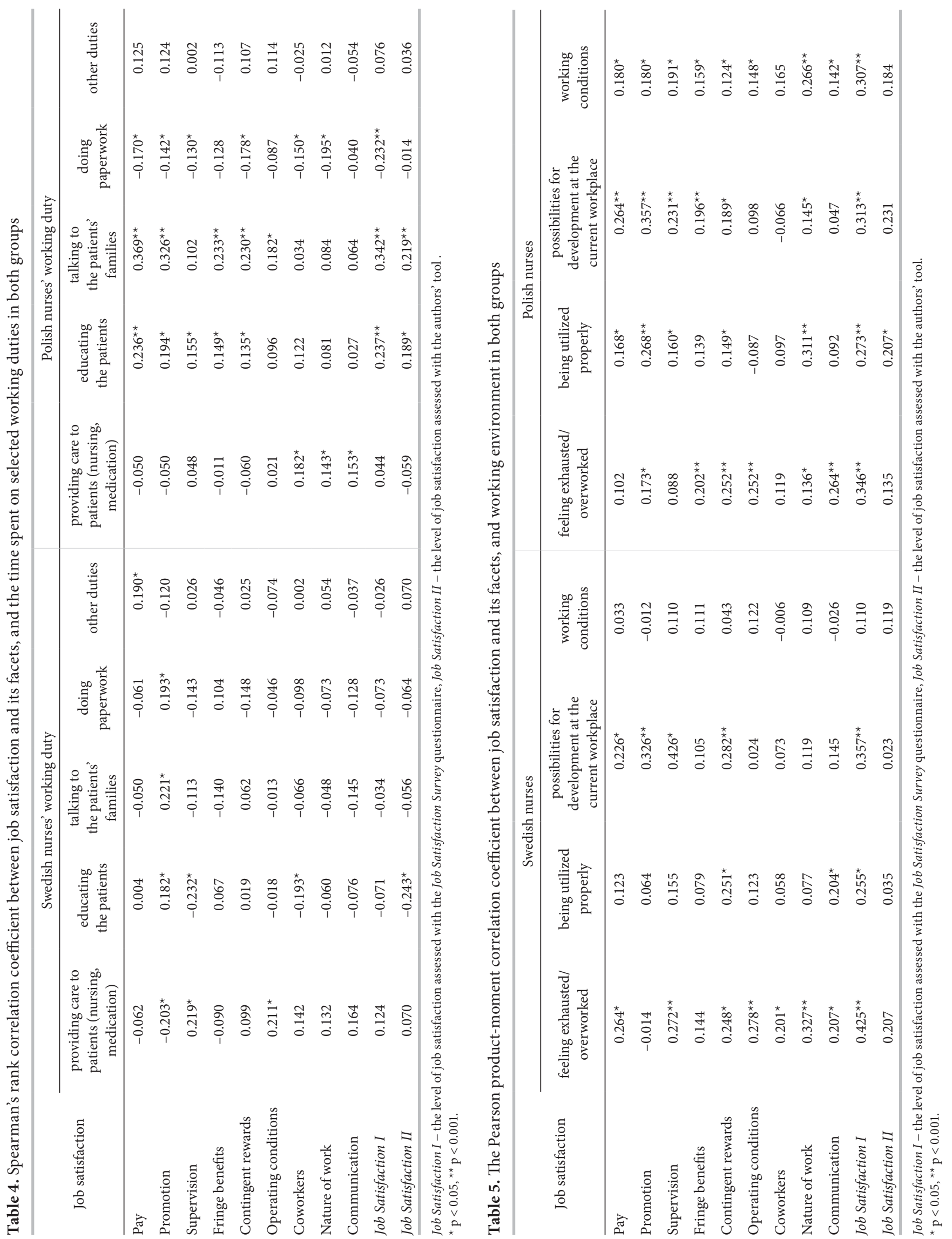


properly were weakly and positively correlated with operating conditions $\left(\mathrm{r}_{\mathrm{p}}=0.311, \mathrm{p}<0.001, \mathrm{~N}=267\right)$. Among Swedish nurses, the possibilities for development at the current workplace were weakly and positively correlated with promotion $\left(\mathrm{r}_{\mathrm{p}}=0.326, \mathrm{p}<0.001\right.$, $\mathrm{N}=141)$ and Job Satisfaction $I\left(\mathrm{r}_{\mathrm{p}}=0.357, \mathrm{p}<0.001\right.$, $\mathrm{N}=141$ ), and moderately correlated with supervision $\left(\mathrm{r}_{\mathrm{p}}=0.426, \mathrm{p}=0.004, \mathrm{~N}=141\right)$. Working conditions were also weakly and positively correlated with Job Satisfaction I among Polish nurses $\left(\mathrm{r}_{\mathrm{p}}=0.307, \mathrm{p}<0.001\right.$, $\mathrm{N}=267$ ) but there was no correlation in this respect among Swedish nurses $\left(r_{p}=0.110, p=0.196, N=141\right)$ (Table 5).

\section{DISCUSSION}

These results show a conformity between Swedish and Polish nurses in the rating of job satisfaction on an ambivalent attitude level. Previous studies among surgical nurses have also found a moderate level of general job satisfaction $[16,17]$. This suggests that there is a potential for improvement of job satisfaction among surgical nurses, and also that surgical care, in general, is not a particularly unsatisfying context to work in as a registered nurse.

According to Herzberg's 2-factor theory, both Swedish and Polish nurses emphasized such motivators as the nature of job and career development as important for job satisfaction; however, the study revealed differences in the level of satisfaction with these aspects. Similarly, the results have shown the relevance of hygiene factors such as remuneration and working conditions. To be more specific, these results indicate important areas for improvement to increase job satisfaction. In accordance with Herzberg's theory, salary, as a hygiene factor, was identified to have the lowest level of satisfaction in both groups of nurses. It is important to consider this in relation to general remuneration among nurses in these countries; the participants' salary (gross) was lower than the average nurses' salary in Poland and Sweden (Poland - EUR 739, Sweden - EUR 3374) [32,33]. Moreover, Swedish nurses earn more than the average salary in their country (EUR 3153), and Polish nurses earn less than the average salary in their country (EUR 880) $[32,33]$. The impact of nurses' low salary on their job satisfaction has been presented previously for Poland [24] as well as for other countries [12,34], and also for surgical nurses [16].

The organizational aspect of the workplace has previously been indicated to be a factor that may influence job satisfaction [35]. The most prominent working condition between the 2 countries in this study has been working shifts. The fact that nurses' shift work impacts on the workplace perceptions has been emphasized by Teclaw and Osatuke [36], who revealed that off-shift nurses were less satisfied with their work-life balance and their supervisors. In contrast to the Swedish nurses involved in this study, many Polish nurses worked overtime. This is known to influence the quality of care [36]. Dall'Ora et al. who conducted a study among 12 European countries revealed that all shifts longer than $8 \mathrm{~h}$ caused a higher level of job dissatisfaction and working overtime was associated with poor nurses' outcomes [37]. Shifts of $12 \mathrm{~h}$ or more for hospital nurses used to be associated with more reports of job dissatisfaction, dissatisfaction with work schedule flexibility and intentions to leave. Weekly working hours have an influence on job satisfaction, quality of life as well as intentions to change jobs also among Norwegian nurses [38]. Swedish nurses presented a lower level of job satisfaction when they worked more hours per week. Our results reveal a surprising correlation between being exhausted and an increased level of general job satisfaction. Morrison and Korol revealed that stress, emotional load and moderate challenge at work could increase job satisfaction [39]. It appears that nurses' exhaustion is caused by psychological stress related to autonomy and responsibility rather than by the number of working hours. A possible interpretation of this is that the more challenging job duties are, and the higher the level of responsibility is, the more nursing work is considered to create satisfactory job conditions. This has also been confirmed in Utriainen et al's study which revealed that challenging, meaningful and well organized duties contribute to hospital nurses' feeling well at work [40]. However, nurses who are exposed to high job demands and few job resources suffer particularly from burnout and, as a consequence, experience reduced emotional and physical well-being, absenteeism, and personnel turnover [41].

The most satisfying aspect of work among both groups was the nature of work but with a small distinction; Polish nurses spent more time on administration as compared to the Swedish nurses. The reason could be that they have to cope with much paper documentation: an issue that could be resolved by using electronic medical records in the future. Morrison and Korol found that administration duties may have a negative influence on nurses' job satisfaction [39]. The time spent with patients and their relatives, especially talking with patients' families and relatives, was correlated with increased job satisfaction. Additionally, a positive influence of the time spent with patients is confirmed in the previous research [22]. 
Both Swedish and Polish nurses were moderately satisfied with career development, which was one of the motivating factors in Herzberg's theory. The most noticeable disproportion between these 2 groups was the range of contingent rewards. The level of Polish nurses' satisfaction with this aspect was significantly lower in this study, which was also supported in the previous research among Polish nurses, which pointed out their limited possibilities for professional development [23]. This result is in contrast to previous publications that emphasize achievements and possibilities for occupational development as central facets of good job satisfaction among nurses [13,24].

\section{Limitations}

A few limitations of this study must be presented. Firstly, although the inclusion and exclusion criteria were successfully applied, this study only included a narrow group of nurses, both in terms of the context and geography. Hence, generalizing these findings outside the context and in other geographical areas than the European Union must take account of these facts. Secondly, the statistical calculations are based on subjective scales from the included measuring instruments. These scales may have been too narrow, too broad or subject to excessive freedom of personal interpretation, which may have caused differences in responses. On the other hand, the response rate was good in both countries. Another limitation is that the power analysis to determine an optimal sample size has not been estimated.

A suggestion for future research in this area is to stratify the questionnaire distribution among different types of caring contexts, hospital sizes, different specialties, patient volumes and acuities, and health care/insurance systems, as well as among additional countries inside the European Union.

\section{Clinical usefulness/adoption}

Nurse managers at surgical wards in the European Union may consider findings from this study to develop a satisfactory work environment for nurses through introducing changes in working time to avoid overtime and longer than 8 -h shifts, proportions of every day nursing duties to focus more on being with patients and families than doing administrative work, and thus giving nurses more opportunities for challenging tasks.

\section{CONCLUSIONS}

Swedish and Polish nurses have presented ambivalence towards job satisfaction, and have been least satisfied with the pay factor which is indicated in this study as an important factor of job satisfaction. Their job satisfaction increased when their exhaustion level was higher, which could be caused by emotional stress related to challenges and a high level of demands, so these aspects should be considered as important for creating a satisfactory work environment. The possibilities of achievements, developing professional skills and promotion may be factors that are necessary in order to be satisfied with a working as a registered nurse. Additionally, shorter work shifts (8-h) and elimination of overtime by employing more staff may be successful interventions to decrease job dissatisfaction. Moreover, to increase job satisfaction among nurses, their duties should be focused more on patients and their families' education rather than on administrative duties. Systems should be adjusted to be simpler and more time-efficient.

\section{REFERENCES}

1. Schultz DP, Schultz SE. Psychology and work today. Warszawa: Wydawnictwo Naukowe PWN; 2012.

2. Herzberg F, Mausner B, Snyderman BB. The motivation to work: With a new introduction by Frederick Herzberg. New York: Transaction Publishers; 1993.

3. Spector PE. Job satisfaction. Application, assessment, cause and consequences. London: SAGE Publications; 1997, https:// doi.org/10.4135/9781452231549.

4. Macey WH, Schneider B. The meaning of employee engagement. Ind Organ Psychol. 2008;1(1):3-30, https://doi. org/10.1111/j.1754-9434.2007.0002.x.

5. Brunetto Y, Xerri M, Shriberg A, Farr-Wharton R, Shacklock K, Newman S, et al. The impact of workplace relationships on engagement, well-being, commitment and turnover for nurses in Australia and the USA. J Adv Nurs. 2013;69(12): 2786-99, https://doi.org/10.1111/jan.12165.

6. Leiter MP, Maslach C. Areas of worklife: A structured approach to organizational predictors of job burnout. In: Perrew PL, Ganster DC, editors. Emotional and physiological processes and positive intervention strategies. Bingley: Emerald Publishing; 2004. p. 91-134.

7. Gurková E, Soosova MS, Harkova S, Ziakova K, Zamboriova $M$. Job satisfaction and leaving intentions of Slovak and Czech nurses. Int Nurs Rev. 2013;60(1):112-21, https://doi. org/10.1111/j.1466-7657.2012.01030.x.

8. Kvist T, Voutilainen A, Mäntynen R, Vehviläinen-Julkunen $\mathrm{K}$. The relationship between patients' perceptions of care quality and three factors: Nursing staff job satisfaction, organizational characteristics and patient age. BMC Health Serv Res. 2014;14:466, https://doi.org/10.1186/1472-6963-14-466. 
9. Saber DA. Frontline registered nurse job satisfaction and predictors over three decades: A meta-analysis from 1980 to 2009. Nurs Outlook. 2014;62(6):402-14, https://doi.org/ 10.1016/j.outlook.2014.05.004.

10. Graham KR, Davies BL, Woodend AK, Simpson J, Mantha SL. Impacting Canadian public health nurses' job satisfaction. Can J Public Health. 2011;102(6):427-31.

11. Alharbi J, Wilson R, Woods C, Usher K. The factors influencing burnout and job satisfaction among critical care nurses: A study of Saudi critical care nurses. J Nurs Manag. 2016;24(6):708-17, https://doi.org/10.1111/jonm. 12386.

12. Rosales RA, Labrague LJ, Rosales GL. Nurses' job satisfaction and burnout: Is there a connection? Int J Adv Nurs Stud. 2013;2(1):1-10, https://doi.org/10.14419/ijans. v2i1.583.

13. O'Keeffe AP, Corry M, Moser DK. Measuring job satisfaction of advanced nurse practitioners and advanced midwife practitioners in the Republic of Ireland: A survey. J Nurs Manag. 2015;23(1):107-17, https://doi.org/10.1111/ jonm.12096.

14. Jonsson S. Psychosocial work environment and prediction of job satisfaction among Swedish registered nurses and physicians - A follow-up study. Scand J Caring Sci. 2012; 26(2):236-44, https://doi.org/10.1111/j.1471-6712.2011. 00924.x.

15. Lu H, Barribal KL, Zhang X, While AE. Job satisfaction among hospital nurses revisited: A systematic review. Int J Nurs Stud. 2012;49(8):1017-38, https://doi.org/10.1016/ j.ijnurstu.2011.11.009.

16. Lambrou P, Kontodimopoulos N, Niakas D. Motivation and job satisfaction among medical and nursing staff in a Cyprus public general hospital. Hum Resour Health. 2010;8:26, https://doi.org/10.1186/1478-44 91-8-26.

17. Davies BA, Ward C, Wooda M, Schultz S, Davies H. Comparison of job satisfaction between experienced medical-surgical nurses and experienced critical care nurses. Medsurg Nurs. 2007;16(5):311-6.

18. Job satisfaction survey, JSS page [Internet]. Spector PE, 1994 [cited 2015 Aug 26]. Available from: http://shell.cas. usf.edu/ pspector/scales/jsspag.html.

19. AbuAlRub RF, Alghamdi MG. The impact of leadership styles on nurses' satisfaction and intention to stay among Saudi nurses. J Nurs Manag. 2012;20(5):668-78, https:// doi.org/10.1111/j.1365-2834.2011.01320.x.

20. Li J, Lambert VA. Job satisfaction among intensive care nurses from the People's Republic of China. Int Nurs Rev. 2008;55(1):34-9, https://doi.org/10.1111/j.1466-7657.2007. 00573.x.
21. Barać I, Prlić N, Plužarić J, Farčić N, Kovačević S. The mediating role of nurses' professional commitment in the relationship between core self-evaluation and job satisfaction. Int J Occup Med Environ Health. 2018;31(5):649-58, https://doi.org/10.13075/ijomeh.1896.01256.

22. Lindqvist R, Alenius LS, Runesdotter S, Ensio A, Jylha V, Kinnunen J, et al. Organization of nursing care in three Nordic countries: Relationships between nurses' workload, level of involvement in direct patient care, job satisfaction, and intention to leave. BMC Nurs. 2014;13:27, https://doi. org/10.1186/1472-6955-13-27.

23. Zielińska-Więczkowska H, Buśk A. [Professional satisfaction of nurses in light of selected factors of work environment]. Pielęg XXI w. 2010;3-4(32-3):5-8. Polish.

24. Kunecka D. [Employee's satisfaction medical service quality]. Probl Hig Epidemiol. 2010;91(3):451-7. Polish.

25. Directive 2013/55/EU of the European Parliament and of the Council of 20 November 2013 amending Directive 2005/36/EC on the recognition of professional qualifications and Regulation (EU). Strasbourg: European Parliament and of the Council; 2013.

26. Raport Naczelnej Rady Pielęgniarek i Położnych. Zabezpieczenie społeczeństwa polskiego w świadczenia pielęgniarek i położnych. Warszawa: Naczelna Izba Pielęgniarek i Położnych; 2015.

27. Socialstyrelsen. Nationella planeringsstödet 2015. Tillgång och efterfrågan på vissa personalgrupper inom hälso- och sjukvård samt tandvård. Stockholm:Socialstyrelsen; 2015.

28. Roche MA, Duffield CM. A comparison of the nursing practice environment in mental health and medical-surgical settings. J Nurs Scholarsh. 2010;42(2):195-206, https:// doi.org/10.1111/j.1547-5069.2010.01348.x.

29. Koch SH, Proynova R, Paech B, Wetter T. The perfectly motivated nurse and the others: Workplace and personal characteristics impact preference of nursing tasks. J Nurs Manag. 2014;22(8):1054-64, https://doi.org/10. 1111/jonm.12083.

30. Chan ZCI, Lung MKY. A systematic literature review of nurse shortage and the intention to leave. J Nurs Manag. 2012;21(4):605-13, https://doi.org/10.1111/j.1365-2834.20 12.01437.x.

31. Sveriges Riksdag [Internet]. Stockholm: Riksdag; 2003 [cited 2019 Jan 7]. Lag (2003:460) om etikprövning av forskning som avser människor. Available from: https://www. riksdagen.se/sv/dokument-lagar/dokument/svensk-forfattningssamling/lag-2003460-om-etikprovning-av-forskning-som_sfs-2003-460.

32. Główny Urząd Statystyczny [Internet]. Warszawa: Urząd; 1995-2015 [cited 2015 Dec 29]. Komunikat w sprawie przeciętnego wynagrodzenia w trzecim kwartale $2015 \mathrm{r}$. 
Available from: http://stat.gov.pl/sygnalne/komunikatyi-obwieszczenia/lista-komunikatow-i-obwieszczen/komunikat-w-sprawie-przecietnego-wynagrodzenia-w-trzecim -kwartale-2015-r-,271,10.html.

33. Larsson M. Lönerapport år 2014. Löner och löneutveckling år 1913-2013 efter klass och kön. Stockholm: Lansorganizationen i Sverige; 2014.

34. Correia Dinis LI, Fronteira I. The influence of job rotation in the job satisfaction of nurses in a surgical service. J Nurs Referência. 2015;5:17-26, https://doi.org/10.12707/ RIV14008.

35. Teclaw R, Osatuke K. Nurse perceptions of workplace environment: Differences across shifts. J Nurs Manag. 2015; 23(8):1137-46, https://doi.org/10.1111/jonm.12270.

36. Kunaviktikul W, Wichaikhum O, Nantsupawat A, Nantsupawat R, Chontawan R, Klunklin A, et al. Nurses' extended work hours: Patient, nurse and organizational outcomes. Int Nurs Rev. 2015;62(3):386-93, https://doi.org/10.1111/ inr.12195.
37. Dall'Ora P, Ball J, Simon M, Aiken LH. Association of $12 \mathrm{~h}$ shifts and nurses' job satisfaction, burnout and intention to leave: Findings from a cross-sectional study of $12 \mathrm{Eu}-$ ropean countries. BMJ Open. 2015;23;5(9), https://doi. org/10.1136/bmjopen-2015-008331.

38. Andersen IH, Hansen T, Grov EK. Norwegian nurses' quality of life, job satisfaction, as well as intention to change jobs. Nord J Nurs Res. 2016;37(2):90-9.

39. Morrison KB, Korol SA. Nurses' perceived and actual caregiving roles: Identifying factors that can contribute to job satisfaction. J Clin Nurs. 2014;23(23-4):3468-77, https:// doi.org/10.1111/jocn.12597.

40. Utriainen K, Ala-Mursula L, Kyngas H. Hospital nurses' wellbeing at work: A theoretical model. J Nurs Manag. 2015;23(6):736-43, https://doi.org/10.1111/jonm.12203.

41. Bakker AB, Le Blanc PM, Schaufeli WB. Burnout contagion among intensive care nurses. J Adv Nurs. 2005;51(3): 276-87, https://doi.org/10.1111/j.1365-2648.2005.03494.x.

This work is available in an Open Access model and licensed under the Creative Commons Attribution-NonCommercial 3.0 Poland License - http:// creativecommons.org/licenses/by-nc/3.0/pl/deed.en. 
Appendix 1. Content of Job Satisfaction II

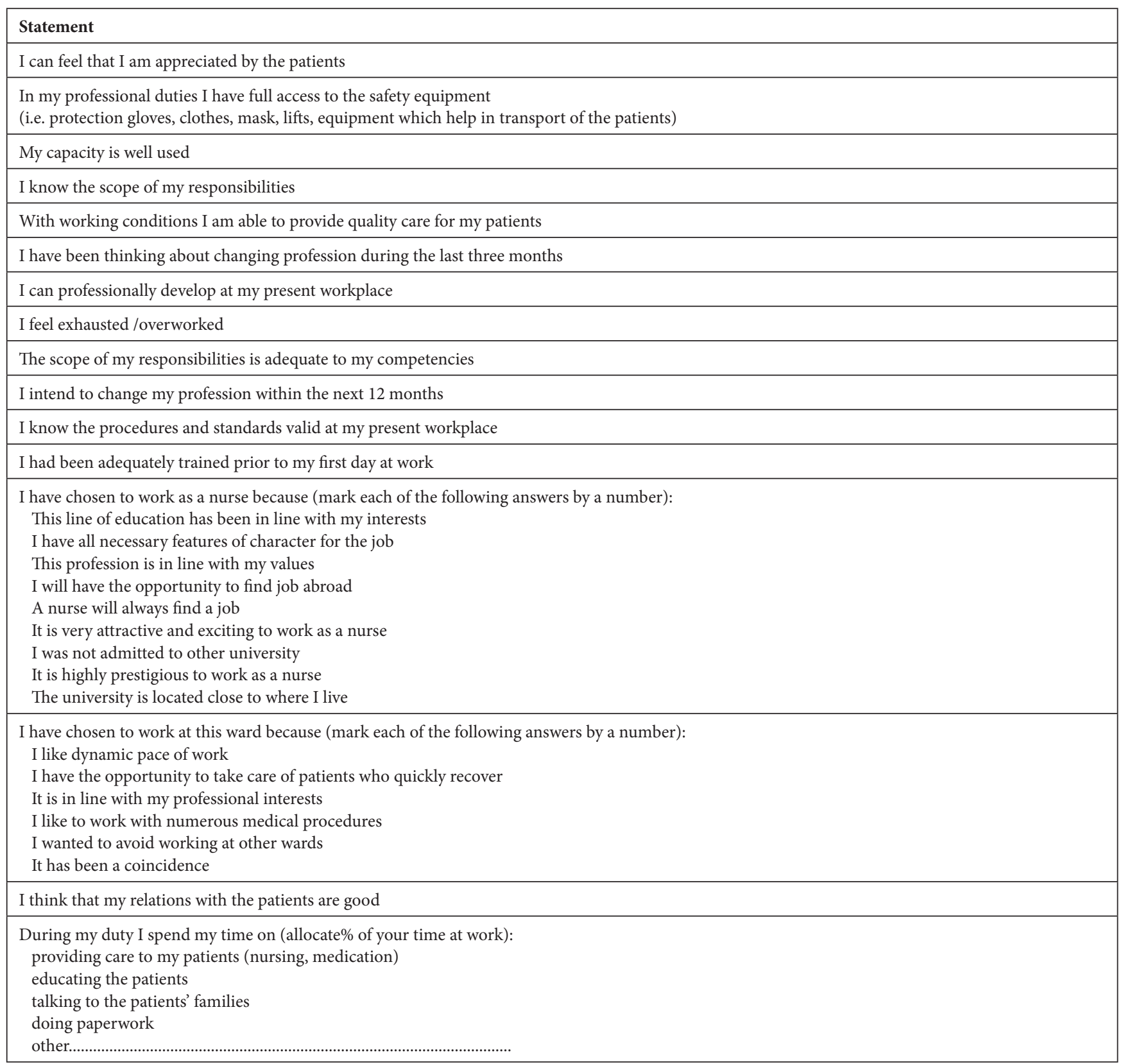

Based on: Zielińska-Więczkowska H, Buśk A. [Professional satisfaction of nurses in light of selected factors of work environment] [23] and Chan ZCI, Lung MKY. A systematic literature review of nurse shortage and the intention to leave [30]. 